\title{
EFEKTIVITAS PENERAPAN SANKSI PIDANA \\ KETENAGAKERJAAN TERHADAP PERUSAHAAN YANG MELAKUKAN \\ PELANGGARAN ETIKA BISNIS \\ Oleh
}

Dani Durahman

Atang Hidayat

\begin{abstract}
ABSTRAK
Pasal 186 Undang-Undang No. 13 tahun 2003 Tentang Ketenagakerjaan dapat disimpulkan belum efektif dalam memaksa para majikan bersikap etis terhadap para karyawannya. Efektifitas Pasal 186 Undang-Undang No. 13 tahun 2003 Tentang Ketenagakerjaan tersebut bisa ditinjau dari tiga tinjauan yaitu filisofis, sosiologis dan yuridis. Secara filisofis, pasal tersebut telah dapat menciptakan keadilan bagi para pihak yang bersengketa yaitu pihak pengusaha dan pihak pekerja. Secara sosiologis, Pasal 186 tersebut belum dirasakan kemanfaatannya dikarenakan masih banyak pengusaha yang melanggar tidak di karenakan sanksi pidana. Secara yuridis, Pasal 186 Undang-Undang No. 13 tahun 2003 Tentang Ketenagakerjaan seharusnya dapat menciptakan kepastian hukum bagi para aktor hubungan industrial. Implementasi penyelesaian perselisihan hubungan industrial lebih mengutamakan mediasi yaitu antara pengusaha dan pekerja, maupun tripartit yang melibatkan pemerintah di dalamnya yaitu Dinas Tenaga Kerja. Perselisihan terlebih dahulu dicarikan solusi melalui musyawarah untuk mufakat. Solusi selanjutnya dapat melalui pengadilan Hubungan Industrial yang kemudian dilanjutkan tuntutan melalui pengadilan negeri apabila keputusan PHI tidak dijalankan, setelah semua proses ditempuh baru proses secara pidana sehingga penerapan Pasal 168 Undang-Undang No. 13 tahun 2003 tentang Ketenagakerjaan menjadi upaya terakhir, yang berakibat susahnya pengusaha terkena sanksi pidana sesuai dengan ketentuan Pasal 168 Undang-Undang No. 13 tahun 2003 Ketenagakerjaan

Kata Kunci : Efektivitas sanksi pidana bidang ketenagakerjaan
\end{abstract}

\section{PENDAHULUAN}

Pancasila adalah warisan nasional kita dan seharusnya menjadi dasar atau semangat dalam dunia usaha. Pancasila merupakan landasan filosofis dan moral dalam seluruh aspek kehidupan Bangsa Indonesia. Namun sangat disayangkan bahwa hubungan industrial yang berdasarkan ideologi Pancasila tersebut jauh dari 
kenyataan. Pelanggaran-pelanggaran etika seringkali terjadi di dunia usaha di Indonesia khususnya dalam hubungan antara pengusaha dan bawahannya. Kasuskasus perselisihan hubungan industrial masuk ke Pengadilan Hubungan Industrial (yang selanjutnya disingkat $\mathrm{HI}$ ) setiap harinya.

Peradilan, dalam kaitan ini Pengadilan Hubungan Industrial, merupakan tempat di mana pengusaha dipaksa bersikap etis secara heteronom terhadap karyawannya. Peradilan, menurut B. Arief Sidharta adalah pranata (hukum) untuk secara formal, imparsial-objektif serta adil-manusiawi, memproses penyelesaian definitif yang hasilnya dirumuskan dalam bentuk sebuah putusan yang disebut vonis, yang implementasinya dapat dipaksakan dengan menggunakan aparat negara (artinya: mengikat semua pihak secara hukum) terhadap konflik antar-subyek hukum, termasuk konflik antar warga masyarakat dan badan hukum publik (pemerintah). Lembaganya disebut pengadilan dan pejabat pengambil putusannya disebut hakim. Aturan prosedural untuk menjamin terselenggaranya peradilan yang imparsial obyektif, yang harus dipatuhi secara ketat, cermat dalam melaksanakan peradilan, disebut Hukum Acara. ${ }^{1}$ Baik pengusaha maupun karyawan adalah subyek-subyek hukum yang harus taat kepada pranata (hukum) yang memberikan penyelesaian terhadap kasus-kasus yang timbul.

Hukum harus berfungsi menertibkan masyarakat, menyelesaikan sengketa secara tertib dan adil dan bertujuan untuk mewujudkan perdamaian dalam masyarakat. Cita-cita hukum sesunggunya bertujuan untuk menciptakan keadilan, kepastian hukum, prediktabilitas dan kehasilgunaan. ${ }^{2}$ Hukum pra-yuridikal dalam hal ini etika harus dapat diejawantahkan dalam hukum baik materil secara substantif dan formil secara ajektif dan seluruh cita-hukum harus terkandung di dalamnya.

Aspek hukum, seperti juga halnya aspek estetis, berkaitan dengan dan bertumpu pada aspek ekonomi. Antara kehidupan hukum dan kehidupan ekonomi

\footnotetext{
${ }^{1}$ B.Arief Sidharta, Praktisi Hukum dan Perkembangan Hukum (Diktat Kuliah) Magister Ilmu Hukum Universitas Langlangbuana Bandung, 2011

${ }^{2}$ B. Arief Sidharta, Hermeneutik: landasan kefilsafatan keberadaan Ilmu Hukum dan praksis hukum. Refika Aditama, Bandung,
} 
pertama-tama terdapat suatu hubungan eksternal. Perkembangan dari kehidupan ekonomi adalah landasan bagi perkembangan kehidupan hukum ${ }^{3}$

Adapun permasalahan yang penulis kemukakan yaitu: "Bagaimana implementasi dalam penyelesaian pelanggaran pidana etika bisnis Hubungan Industrial dalam konteks ketenagakerjaan?”

\section{TINJAUAN TEORI}

Etika atau ethics dalam Bahasa Inggris diartikan sebagai the study of the general nature of morals and of the specific moral choices to be made by a person: moral philosophy. ${ }^{4}$ Etika menurut definisi di atas merupakan studi mengenai moralitas, suatu filsafat moral.

Menurut L. Sinour Yosephus, kata etika berasal dari bahasa Yunani ethos (tunggal) yang berarti adat, kebiasaan,watak, ahlak, sikap, perasaan, dan cara berpikir. Bentuk jamak dari ethos adalah ta etha yang berarti adat kebiasaan atau pola pikir yang dianut oleh suatu kelompok orang yang disebut masyarakat atau pola tindakan yang dijunjung tinggi dan dipertahankan oleh masyarakat tersebut. Ta etha inilah yang menjadi acuan dari etika sebagai ilmu. ${ }^{5}$

Etika sebagai cabang filsafat yang memfokuskan diri kepada moralitas dapat dipelajari dan dikembangkan dalam berbagai metoda, tetapi ada tiga pendekatan utama yang banyak dipergunakan yaitu; deskriptif, konseptual, dan preskriptif (normatif). Pendekatan deskriptif dan konseptual menjelaskan serta menganalisa moralitas tanpa memilih posisi moral tertentu. Pendekatan normatif memilih posisi moral tertentu atau teori etika tertentu untuk menilai sesuatu.

Keinginan untuk memperoleh keuntungan pribadi atau bahkan kerakusan menimbulkan beberapa masalah etis. Bisnis seringkali berisi orang-orang yang mementingkan keuntungan sendiri lebih dari yang lainnya, walaupun hal itu

3 Hernawati RAS dan Dani Durahman, "Aspek Hukum dalam Penyelenggaraan Bisnis Perhotelan”, Jurnal Ilmiah Universitas Batanghari Jambi, Vol. 20 (3), Oktober 2020, hlm.1033

${ }^{4}$ The American Heritage Dictionary, 1996, hlm. 29

${ }^{5}$ L.Sinour Yosephus, , Etika, Gramedia Jakarta, 2010, hlm 3 
membahayakan atau merugikan orang lain, perusahaan, atau bahkan masyarakat. Orang seperti ini disebut dengan ethical egoist. Yang menjadi cirinya adalah kerakusan dan kepentingan diri sendiri.

Sehubungan dengan hal di atas, di dalam Ilmu Manajemen dikenal tiga tipe manajemen yaitu moral manajenen, immoral manajemen, dan amoral manajemen. Moral manajemen sangat memperhatikan nilai-nilai moral dalam menjalankan suatu bisnis. Ini merupakan tipe manajemen yang paling ideal. Immoral manajemen sedikit melakukan pelanggaran moral seperti misalnya memberhentikan karyawan tanpa memberikan pesangon sesuai dengan haknya. Amoral manajemen sama sekali tidak mempedulikan nilai-nilai moral yang ada. Manajemen seperti ini menghalalkan segala cara untuk mencapai tujuannya.

Pengertian korporasi hanya meliputi badan hukum dan tidak termasuk bukan badan hukum karena beliau menekankan harus ada tiga organ walaupun pada awal rumusannya beliau menyatakan tanpa melihat bentuk organisasinya (tentu hal ini meliputi CV, Fa, P0, atau UD). Hal ini semakin jelas bahwa korporasi itu hanya badan hukum karena beliau menyatakan batas umumnya ditentukan dalam anggaran dasar. Sedangkan CV, Fa, P0, dan UD jarang sekali membuat/ mempunyai anggaran dasar perusahaan, paling ada akta pendirian belaka sebab sebagian besar pemilik dan pendirinya perorangan dan/atau bersama keluarga.

Pendapat yang telah dikemukakan oleh E. Utrech berkaitan dengan badan hukum sebagai subjek hukum tindak pidana, yaitu:

"Perlu dikemukakan beberapa hal sebelum tahun 1951 (Hamste- vert LN 1951 Nr. 90 Jo. LN 1953 Nr. 4) dan tahun 1955 (LN 1955 Nr. 27), maka hukum pidana tertulis positif tidak mengenal hukuman terhadap badan hukum. Lihatlah keputusan $\mathrm{HgH}$ tanggal 5 Agustus 1925 T. 127 hal 164. Setelah tahun 1951 dan 1955, maka hukum pidana tertulis positif mengenai hukuman terhadap badan hukum. Akan tetapi hukum pidana yang tercantum dalam KUH Pidana tetap masih belum mengenal hukuman kolektif (colective straffen) karena peraturan tahun 1951 maupun peraturan tahun 1955 yang 
telah penulis singgung di atas, tidak mengubah KUH Pidana tersebut, tetapi tinggal suatu peraturan yang tersendiri. Hukum pidana menurut KUH Pidana tetap masih mengenal hukuman individual saja. Hukuman pidana menurut KUH Pidana tetap masih bersifat individualistis ( individualistis karakter van het strafwetbook). ${ }^{6}$

Selanjutnya, Utrech mengemukakan:

"Pasal 59 KUHPidana, yang mengandung ancaman hukuman terhadap pengurus dan komisaris suatu badan hukum (rechtspersoon) (korporasi dan yayasan) karena disangka/diduga telah melakukan suatu delik, hanya berlaku dalam hal pelanggaran saja. ${ }^{7}$

\section{PEMBAHASAN}

Kata efektif, dalam Bahasa Inggris, effective menurut The American Heritage Dictionary didefinisikan sebagai producing or capable of producing a desired effect dan dapat diterjemahkan secara bebas bahwa sesuatu bisa dikatakan efektif bila dapat mencapai tujuan yang dimaksud. Efektifitas suatu undang undang dapat dilihat dari tiga aspek yaitu filosofis, sosiologis, dan yuridis. Secara filosofis, apakah undangundang tersebut dapat menciptakan rasa keadilan dalam masyarakat atau tidak.

Buruh sebagai bagian integral dari masyarakat Indonesia perlu dilindungi dan diwujudkan kesejahteraannya. Dengan kata lain, Pasal 186 Undang-Undang No 13 Tahun 2003 Tentang Ketenagakerjaan tersebut diharapkan dapat menciptakan keadilan dalam masyarakat tenaga kerja di Indonesia.

Implementasi dalam penyelesaian pelanggaran etika bisnis hubungan industrial dapat dilakukan oleh para aktor hubungan industrial yaitu pengusaha, pekerja dan pemerintah. Karena hubungan industrial di Indonesia berdasarkan Pancasila, maka penyelesaian berdasarkan musyawarah untuk mufakat harus didahulukan. Mediasi antara pihak yang berperkara dengan bantuan Dinas Tenaga Kerja harus terlebih dahulu dilakukan. Bila mediasi mengalami deadlock, maka

\footnotetext{
${ }^{6}$ E. Utrech, Hukum Pidana I, Jakarta, 1960, hlm. 99.

${ }^{7}$ Ibid.,hlm.98.
} 
penyelesaian bisa diajukan ke PHI dengan menyertakan risalah hasil perundingan tripartit.

Kepatuhan masyarakat hubungan industrial terjadi baik itu karena sanksi yang berdasarkan rasa takut maupun karena kesadaran yang berdasarkan tanpa rasa takut. Kepatuhan karena berdasarkan rasa takut karena sanksi disebut tindakan etis yang dipaksakan karena ketaatan kepada hukum (compliance with the law). Dari contoh tiga kasus, compliance with the law merupakan alasan para majikan bersikap etis terhadap para karyawannya. Ternyata budaya hukum masyarakat hubungan industrial bukan didasarkan karena kesadaran hukum, tetapi rasa takut menanggung konsekuensi karena melanggar hukum.

Pemerintah telah menyediakan sarana dan prasarana yang lengkap dalam menciptakan keadilan hukum dalam masyarakat hubungan industrial. Hal ini bisa dilihat dari paying undang-undang tentang ketenagakerjaan, serikat kerja, dan Pengadilan Hubungan Industrial. Dinas Tenaga Kerja juga dapat ditemui di seluruh wilayah kota/kabupaten di Indonesia.

Tiga Pihak masyarakat hubungan industrial yaitu pengusaha yang diwakili oleh Apindo, para pekerja yang diwakili oleh Serikat Kerja, dan pemerintah yang diwakili oleh Dinas Tenaga Kerja, terlibat aktif di dalam usaha menciptakan kesejahteraan masyarakat hubungan industrial Tampaknya budaya hukum dalam masyarakat hubungan industrial telah cukup dipengaruhi oleh hadirnya UndangUndang No. 13 tahun 2003 Tentang Ketenagakerjaan, khususnya ancaman pidana dalam Pasal 186. Semua orang yang bekerja di dalam wilayah Negara Indonesia, apapun pekerjaannya, selama pekerjaan itu halal, maka baik pekerja maupun majikannya harus tunduk kepada Undang- Undang No. 13 Tahun 2003 Tentang Ketenagakerjaan.

\section{PENUTUP}

Pasal 186 Undang-Undang No. 13 tahun 2003 Tentang Ketenagakerjaan dapat disimpulkan belum efektif dalam memaksa para majikan bersikap etis terhadap para karyawannya. Efektifitas Pasal 186 Undang-Undang No. 13 tahun 2003 Tentang 
Ketenagakerjaan tersebut bisa ditinjau dari tiga tinjauan yaitu filisofis, sosiologis dan yuridis. Secara filisofis, pasal tersebut telah dapat menciptakan keadilan bagi para pihak yang bersengketa yaitu pihak pengusaha dan pihak pekerja. Secara sosiologis, Pasal 186 tersebut belum dirasakan kemanfaatannya dikarenakan masih banyak pengusaha yang melanggar tidak di karenakan sanksi pidana. Secara yuridis, Pasal 186 Undang-Undang No. 13 tahun 2003 Tentang Ketenagakerjaan seharusnya dapat menciptakan kepastian hukum bagi para aktor hubungan industrial. Implementasi penyelesaian perselisihan hubungan industrial lebih mengutamakan mediasi yaitu antara pengusaha dan pekerja, maupun tripartit yang melibatkan pemerintah di dalamnya yaitu Dinas Tenaga Kerja. Perselisihan terlebih dahulu dicarikan solusi melalui musyawarah untuk mufakat. Solusi selanjutnya dapat melalui pengadilan Hubungan Industrial yang kemudian dilanjutkan tuntutan melalui pengadilan negeri apabila keputusan PHI tidak dijalankan, setelah semua proses ditempuh baru proses secara pidana sehingga penerapan Pasal 168 Undang-Undang No. 13 tahun 2003 tentang Ketenagakerjaan menjadi upaya terakhir, yang berakibat susahnya pengusaha terkena sanksi pidana sesuai dengan ketentuan Pasal 168 Undang-Undang No. 13 tahun 2003 Ketenagakerjaan.

\section{DAFTAR PUSTAKA}

B. Arief Sidharta, Praktisi Hukum dan Perkembangan Hukum (Diktat Kuliah) Magister Ilmu Hukum Universitas Langlangbuana Bandung, 2011

-----------------------, Hermeneutik: landasan kefilsafatan keberadaan Ilmu Hukum dan praksis hukum. Refika Aditama, Bandung,

E. Utrech, Hukum Pidana I, Jakarta, 1960,

Hernawati RAS dan Dani Durahman, “Aspek Hukum dalam Penyelenggaraan Bisnis Perhotelan", Jurnal Ilmiah Universitas Batanghari Jambi, Vol. 20 (3), Oktober 2020

L.Sinour Yosephus, , Etika, Gramedia Jakarta, 2010

Lalu Husni, Pengantar Hukum Ketenagakerjaan Indonesia Edisi Revisi, Rajawali Pers, Jakarta 2003, 